\title{
Urdimento
}

Revista de Estudos em Artes Cênicas

E-ISSN: 2358.6958

\section{Crítica, cura e curadoria}

Castiel Vitorino Brasileiro

Dodi Tavares Borges Leal

Para citar este artigo:

BRASILEIRO, Castiel Vitorino; LEAL, Dodi Tavares Borges. Crítica, cura e curadoria. Urdimento, Florianópolis, v. 1, n. 40, mar./abr. 2021.

do) DOI: http:/dx.doi.org/10.5965/1414573101402021e0401

Este artigo passou pelo Plagiarism Detection Software | iThenticate 
Castiel Vitorino Brasileiro ${ }^{1}$

Dodi Tavares Borges Leal²

\section{Resumo}

Nesta conversa, realizada no quadro da Jornada da Associação Brasileira de Críticos de Arte (ABCA) de 2020, em parceria com a Universidade Federal do Sul da Bahia, a performer e psicóloga Castiel Vitorino Brasileiro e a professora e pesquisadora Dodi Leal refletem sobre as interfaces da crítica, da cura e da curadoria. Como performar o invisível? Trata-se nesta conversa das imagens profundas, dos modos existenciais e dos machucados corporais da terra e de como as nossas ritualidades, nossas sabenças encantadas, nossas bruxarias e nossas macumbarias pretas, indígenas e trans são perigos à colonialidade branca e cisgênera da arte. Quais os rasgos da crítica de arte a partir da cura Bantu? Quais as amarras da curadoria de arte que se desfazem a partir da cura anticolonial travesti? A curanderia é o exercício de redirecionamento clínico (crítica cirúrgica de arte) de algumas práticas artísticas institucionais que precisam ser abandonadas, percebendo também as que devem ser reformuladas.

Palavras-chave: Processos de cura. Curadoria. Crítica de arte. Anticolonialidades.

${ }^{1}$ Artista visual, macumbeira e psicóloga mestranda no programa de Psicologia Clínica da PUC-SP. Pesquisa e inventa relações em que corpos não-humanos se desprendem das amarras da colonialidade. Desenvolve estéticas macumbeiras de sua Espiritualidade e Ancestralidade Travesti. Idealizadora do projeto de imersão em processos criativos decoloniais Devorações. https://castielvitorinobrasileiro.com castielvitorinob@gmail.com

(9) http://lattes.cnpq.br/1932549019417562 (D) https://orcid.org/0000-0001-9779-9151

2 Professora Adjunta do Centro de Formação em Artes e do Instituto de Humanidades, Artes e Ciências da Universidade Federal do Sul da Bahia. Doutora em Psicologia Social pelo Instituto de Psicologia da Universidade de São Paulo e Licenciada em Artes Cênicas pela Escola de Comunicações e Artes da Universidade de São Paulo. dodi@alumni.usp.br

http:/lattes.cnpq.br/0796146302257664

(D) https://orcid.org/0000-0002-1875-8616 


\title{
Criticism, healing and curatorship
}

\begin{abstract}
In this conversation, held within the framework of the Journey of the Brazilian Association of Art Critics (ABCA) of 2020, in partnership with the Federal University of Southern Bahia, the performer and psychologist Castiel Vitorino Brasileiro and professor and researcher Dodi Leal reflect on the interfaces of criticism, healing and curatorship. How to perform the invisible? This conversation is about deep images, existential modes and bodily injuries of the earth and how our rituals, enchanted wisdoms, witchcraft and black, indigenous and trans macumbarias are dangers to the white and cisgender coloniality of art. What are the characteristics of art criticism from the Bantu cure? What are the ties of art curatorship that come undone from the transvestite anti-colonial cure? The 'curanderia' is the exercise of clinical redirection (surgical criticism of art) of some institutional artistic practices that need to be abandoned, also realizing those that must be reformulated.
\end{abstract}

Keywords: Healing processes. Curatorship. Art criticism. Anti-colonialities.

\section{Crítica, cura y curaduría}

\section{Resumen}

En esta conversación, realizada en el marco de la Jornada de la Asociación Brasileña de Críticos de Arte (ABCA) de 2020, en alianza con la Universidad Federal del Sur de Bahía, la performer y psicóloga Castiel Vitorino Brasileiro y la profesora e investigadora Dodi Leal reflexionan sobre las interfaces de crítica, cura y curaduría. ¿Cómo performar en lo invisible? Esta conversación trata sobre imágenes profundas, modos existenciales y lesiones corporales de la tierra y cómo nuestros rituales, sabidurías encantadas, brujería y macumbarias negras, indígenas y trans son peligros para la colonialidad blanca y cisgénera del arte. ¿Cuáles son las características de la crítica de arte de la cura bantú? ¿Cuáles son los lazos de la curaduría de arte que se deshacen desde la cura anticolonial travesti? La curanderia es el ejercicio de redirección clínica (crítica quirúrgica del arte) de algunas prácticas artísticas institucionales que necesitan ser abandonadas, dándose cuenta también de aquellas que deben ser reformuladas.

Palabras clave: Procesos curativos. Curaduría. Crítica de arte. Anticolonialidades. 
A conversa Crítica, cura e curadoria foi realizada em 27 de novembro de 2020, transmitida pela plataforma do YouTube3. Ela ocorreu em meio à pandemia causada pelo vírus SARS-COV-2. O encontro virtual se deu no quadro da Jornada da Associação Brasileira de Críticos de Arte (ABCA 2020) e versou sobre as interfaces da crítica, da cura e da curadoria buscando interrogar os espaços de produção e de apreciação da chamada arte contemporânea levando em conta seus limites e fracassos.

As questões motivadoras para a conversa foram:

Como performar o invisível? Procuraremos tratar nesta conversa das imagens profundas, dos modos existenciais e dos machucados corporais da terra e de como as nossas ritualidades, nossas sabenças encantadas, nossas bruxarias e nossas macumbarias pretas, indígenas e trans são perigos à colonialidade branca e cisgênera da arte.

Quais os rasgos da crítica de arte a partir da cura Bantu? Quais as amarras da curadoria de arte que se desfazem a partir da cura anticolonial travesti? A curanderia é o exercício de redirecionamento clínico (crítica cirúrgica de arte) de algumas práticas artísticas institucionais que precisam ser abandonadas, percebendo também as que devem ser reformuladas. Nos interessa semear novos matemas não-higienistas e colher danças de memórias, lógicas onde acaba-se definitivamente a ilusão do amor colonial e sua dominação (do-homem-nação).

Estes esgarçamentos de cura que fazem tremor à crítica e curadoria de artes ocidenlitistas, e que dão vazão a dimensionalidades temporais e espaciais sudacas-africanas-orientais que derrubam os padrões e os patrões da arte.

A abertura do encontro foi realizada por Alessandra Simões, professora na Universidade Federal do Sul da Bahia (UFSB), onde atua como Coordenadora de Extensão; tem graduação em Comunicação Social (UNESP), Mestrado Interunidades em Estética e História da Arte (USP) e Doutorado no Programa Interunidades Integração da América Latina (PROLAM-USP)/linha de pesquisa:

${ }^{3}$ ASSOCIAÇÃO BRASILEIRA DE CRÍTICOS DE ARTE (ABCA). Mesa: Crítica, Cura e Curadoria. Conversa entre Castiel Brasileiro e Dodi Leal. Duração: 01:47:40. Data: 27 nov. 2020. Link na íntegra: https://www.youtube.com/watch?v=FRe2fPXy554\&t=3361s\&ab_channel=JornadaABCA. 
Comunicação e Arte. Membra da Associação Brasileira de Críticos de Arte (ABCA) e da Associação Internacional de Críticos de Arte (AICA). Como debatedoras, a mesa foi composta por:

Castiel Vitorino Brasileiro - Artista visual, macumbeira e psicóloga formada em Universidade Federal do Espírito Santo (UFES). Atualmente mestranda no programa de Psicologia Clínica da PUC-SP sob orientação da Profa. Dra. Suely Rolnik. Pesquisa e inventa relações em que corpos não-humanos se desprendem das amarras da colonialidade. Compreende a macumbaria como um jeito de corpo necessário para que a fuga aconteça. Dribla, incorpora e mergulha na diáspora Bantu, e assume a vida como um lugar perecível de liberdade. Atualmente, desenvolve estéticas macumbeiras de sua Espiritualidade e Ancestralidade Travesti. Nasceu em 1996 em Vitória/Espirito Santo - Brasil.

Dodi Leal - Travesti educadora e pesquisadora em Artes Cênicas. Professora do Centro de Formação em Artes da Universidade Federal do Sul da Bahia (UFSB). Dedica-se aos estudos da performance e visualidades da cena e do corpo, perpassando por ações de crítica teatral, curadoria e pedagogia das artes. Doutora em Psicologia Social (IP-USP), com estágio doutoral no programa de Doutoramento em Estudos Artísticos da Faculdade de Letras da Universidade de Coimbra, concentração na área de Estudos Teatrais e Performativos, e licenciada em Artes Cênicas (ECA-USP). Líder do Grupo de Pesquisa Pedagogia da Performance: visualidades da cena e tecnologias críticas do corpo.

O texto que aqui apresentamos resulta de uma transcrição feita pelo estudante de graduação em artes da UFSB, Marconi Sales, com pequenas adaptações para o formato escrito, permitindo uma melhor fluência na leitura. 


\section{Dodi Leal}

"Eu determino que termine, aqui e agora. Eu determino que termine em mim, mas não acabe comigo. Determino que termine em nós e desate. E que amanhã, que amanhã possa ser diferente pra elas, que tenham outros problemas e encontrem novas soluções, e que eu possa viver nelas, através delas e em suas memórias" (Linn da Quebrada). "Uma chama não perde nada, quando ascende outra chama”. Provérbio africano, abertura do livro Um Defeito de Cor da autora Ana Maria Gonçalves.

Castiel, muito obrigada por estar aqui comigo nessa tarde, prazer enorme conversar com você. Te admiro muito, e tenho uma pulsão de vida muito grande ao ver tua obra, a conhecer teu pensamento, ao fluir as ideias que você produz com sua prática artística e tua prática clínica. Estou aqui muito feliz também em dividir contigo questionamentos que eu venho trazendo em meu percurso prático enquanto professora, crítica e curadora de arte. Esse desafio nosso de pensar em crítica, cura e curadoria.

Eu queria primeiramente agradecer, agradecer ao evento, e é isso mesmo. Elas estarão aqui, vão chegar... não queira. Então quero passar pra você se apresentar e contar sua trajetória. Você pode trazer questionamentos sobre esse tema, crítica, cura e curadoria, que você está investigando em seu trabalho artístico.

Inclusive conversamos ontem um pouco, para combinar os caminhos possíveis para a conversa de hoje, e espero que possamos em breve nos conhecer pessoalmente. Você está aí em São Paulo, e eu aqui na Bahia. Lembro que conversamos sobre seu trabalho e como eventualmente você já traz em seu próprio fazer, o exercício da crítica e curadoria de arte. Em seu mestrado também você faz essa investigação, queria muito que você compartilhasse o que puder. Tenho algumas perguntas que vou trazer depois desse momento. "Vamo ouvir as bruxona, vamo lá”. Obrigada Castiel. 


\section{Castiel Brasileiro}

Obrigada Dodi, obrigada ao evento pelo convite, obrigada a todas as pessoas que estão aqui e irão compor junto a nós esse encontro. Sou Castiel Vitorino Brasileiro, nasci no morro da Fonte Grande, em Vitória, capital do Espírito Santo. E o Espírito Santo é uma encruzilhada entre Rio de Janeiro, África, Bahia e Minas Gerais. Então quero dizer sobre essa encruzilhada e conversar a partir de três pilares: a palavra, a arte e o corpo.

Sobre a palavra, gostaria de perguntar: Por que estou aqui? Por que faz sentido minha presença aqui, com vocês? Por que fui convidada? Por que vocês querem me ouvir? Por que vocês querem me tocar e viver minha obra? Ano passado (2019) eu lancei um livro que se chama Macumbas de Travesti, Feitiços de Bicha e um dos títulos desse livro também é Quando encontro vocês. Mas, hoje, a pergunta que quero dizer é: Por que querem me encontrar? Pois, nesse desejo de encontro, não há nada de novo, e no que eu faço não há novidade. O que há é uma outra forma de fazer, aquilo que já se faz há uma centena de milhares de anos. É aquilo que se faz presente não só em nossa espécie Homo sapiens sapiens, mas também aquilo que acontece a partir de outros animais, vegetais e minerais. Outras vidas de outros reinos já fazem isso que estou fazendo, mas porque vocês querem justamente o que eu faço, da forma que eu faço, na particularidade que eu faço? Que desejo é esse? E quando chegam a mim, o que querem ouvir de mim? O que esperam de mim?

Esperam a linearidade? Esperam a perfeição? Esperam a salvação? Esperam a cura? Bem, eu não acredito em salvação, travestis não salvam ninguém, pessoas negras não salvam ninguém, ou, pelo menos, eu, uma travesti negra, não salvo ninguém. E também não acredito na evangelização, ou, pelo menos, a única evangelização que acredito é aquela que me possibilita trair a palavra, trair a linguagem, que é aquela feita por uma amiga chamada Ventura Profana. Mas aqui não direi sobre evangelização, quem a faz que fale! Eu quero dizer sobre meu rompimento com a demanda da salvação. Não acredito em salvação pois a salvação, no contexto moderno, está circunscrita no desejo de catequizar e na possibilidade de modificar a alma. 
Então na radicalidade que a minha vida me ensina, e que meus ancestrais desejam que eu fale, pergunto-me: como salvar um corpo que não há alma? De algum modo e de vários modos, nunca houve a possibilidade de salvação a mim, ou das pessoas que me antecederam, porque a África e o Ser africano - e subsujeito, e animalizado, e objetificado - nunca foi percebido como um Ser compatível com a ideia de Alma Moderna, ou seja, com a ideia de memória. Então não temos memórias, não temos almas, no contexto da modernidade. Mas, em parâmetros vitais que não os modernos capitalistas, fundamentos Bantu nos ensina que em nossas vidas há memórias/almas que devem ser cultuadas.

Esta é a demanda: nos perceber em alma e cultuar nossas almas. Não acredito em salvação porque ela é uma experiência linear, e aqui não existe ingenuidade em mim. Eu não nasci artista, não nasci negra, não nasci travesti, tornei-me todas essas e tantas outras palavras, dizeres, linguagens e formas. Me tornei uma forma, mas não uma fórmula. A forma que hoje eu habito e que eu construo em meu corpo não é uma fórmula, por isso digo que travestis não salvam ninguém, em especial as negras. Meu tempo é precioso pra tentar salvar alguém, não acredito em salvação.

Não acredito na salvação porque a transsexualidade, transição de gênero, ou a escuridão da minha pele não me garante nada. Nada se garante, porque a experiência de construir garantias para a vida é colaborar de um modo ingênuo com a modernidade. Então esperar que algo aconteça numa garantia, é viver numa linearidade, ou seja, farei uma coisa agora porque ontem me permitiu, e hoje farei algo que possibilitará coisas que aconteceram amanhã. Mas tudo pode mudar.

Eu sou uma travesti, logo eu penso de uma determinada forma? Eu sou uma pessoa negra, logo penso de uma determinada forma? Isso são as mitologias do gênero e raça operando em minha vida, e, novamente, não há nenhuma ingenuidade em mim. Talvez aconteça em vocês, e existem várias formas de lidar com essa ingenuidade. Uma delas é a terapia, mas se tratando de pessoas brancas ou cisgêneras, a ingenuidade deve ser vista de um outro modo, e talvez não seja ingenuidade que aconteça, mas sim uma sagacidade. Há sempre uma sagacidade colonial, acontecendo no desejo de vivenciar a minha existência, e essa sagacidade 
acontece há séculos. Não há novidade aqui, nem eu ou você anuncia novidades, anunciamos a perpetuação de um modo de ser estar, a perpetuação a partir de uma diferença.

Então veja, na construção de Minas Gerais, existia uma crença que todo senhor de escravos deveria ter uma negra raptada de uma região específica de África que Portugal nomeava de Minas. Senhores de escravos Mineiros, em específico de Ouro Preto, acreditavam - fetiche - que era preciso ter dentro de sua casa, uma pessoa africana que vinha de uma região específica, porque essa pessoa te traria sorte. Esse é o convite para estar com vocês hoje? Eu trago sorte? A minha presença é necessária pra quê? Porque a minha presença é necessária nesse evento? Porque vocês me querem em suas casas com suas famílias?

Esse fetiche continua acontecendo, após a desgraçada e incompetente Lei Áurea. A demanda da liberdade ainda é, e sempre vai ser, em um tempo linear, uma demanda. Se a linearidade é racial então podemos conversar assim, fazer previsões de violências raciais. A única previsão possível é de que a violência racial continuará acontecendo, então eu tenho o desejo de continuar produzindo liberdades.

Eu acredito na palavra, e talvez eu não a acredite. É uma contradição em que eu gosto de gozar. Eu faço mestrado, então não há porque descartar a palavra e o uso da linguagem, pelo contrário, o processo de mestrado é a possibilidade de utilizar de um outro modo essa palavra, nas possibilidades que não são todas pessoas que criam, então eu estou tentando construir outras possibilidades de se relacionar com a linguagem que violenta a todo momento. Estamos falando em português, quer violência maior que essa?

A violência é a nomeação, sempre que eu for nomeada eu serei violentada, esse momento é uma conversa como qualquer outra, mas porque a minha excelência não consegue ser nomeada de palestra? Porque o encontro entre eu e Dodi não foi nomeado de palestra ou de conversa, e sim foi anunciado como um momento insondável, indizível, indescritível? Por que somos indescritíveis e insondáveis? Ou melhor, porque vocês utilizam dessa forma para se relacionar 
com nossa excelência, com a nossa potência? Que medo é esse da linguagem? Que medo é esse da palavra travesti? Que medo é esse da palavra negro?

Na última década, existe algo interessante acontecendo no contexto brasileiro, que é a relação cultural com a palavra branco e seus significados: tentativas de apagamento, desresponsabilização, esquecimento da branquitude que nos constitui. Que negociação e sagacidade é essa que fazemos com a linguagem? Novamente, não existe ingenuidade entre nós, não existe salvação, o que existe é a negociação, e na negociação algo se perde para ganhar, e algo se ganha perdendo. Estamos ganhando e perdendo nesse momento, e não há ingenuidade entre nós.

Bem, eu pertenço a uma espécie animal, Homo sapiens sapiens, que tá aí nesse planeta há algum tempo, e a escuridão da minha pele junto com a transfiguração do meu corpo e a modificação da minha alma, no Brasil e no contexto latino-americano sou nomeada de travesti e de negra. E também sou artista, eu não nasci artista, me tornei, no sentido de querer ser. Acordei e falei "eu quero ser", com todos as demandas brasileiras de artes, com todos os desafios e desgraças. Eu vim de um estado que tem uma lacuna enorme de crítica e curadoria, e eu não tô dizendo de crítica e curadoria negra, indígena ou travesti. Estou dizendo de crítica e curadoria para além dos regimes de visibilidade que geralmente a arte contemporânea tem desejado e orientado a suas práticas.

Então, esse desafio em crítica e curadoria me fez criar a minha excelência, me convidando a todo momento a me obrigando a conseguir dizer sobre o meu próprio trabalho. Existe uma relação ética comigo mesma, e a relação que desenvolvo em dizer sobre meu próprio trabalho sem precisar que um curador fale sobre ele. É uma relação limitada, como qualquer relação será, mas essa é uma relação possível, assim como é possível uma relação desenvolver críticas com outras pessoas que trabalham na curadoria, sobre o meu trabalho. São relações possíveis, e aqui não existe uma fórmula do tipo "ou eu escrevo ou eu deixo outra pessoa escrever". Inclusive eu não tenho o poder de deixar, existe uma responsabilidade da curadoria em relação a meu trabalho, escrevam o que quiserem, falem o que quiserem sobre mim e minha obra. Essa não é minha 
responsabilidade, é a sua ideia sobre mim, e o que vocês escrevem ou o que pensam, é uma responsabilidade de vocês críticos, não minha.

Aí vamos, juntos ou juntas, criando possibilidades de trabalho, onde uma crítica seja favorável a transmutação que eu cultuo, uma crítica que possibilite eu continuar cultuando a transfiguração da minha alma e possibilite que nós de forma coletiva continuemos gozando na contradição. Mas não aquela contradição que elimina, essa contradição que o presidente Bolsonaro tanto produz antes mesmo de seu mandato iniciar. Não é essa contradição de eliminação da diferença. A contradição é um encontro de caminhos, e nesse encontro existe a decisão por qual caminho tomaremos, um dos caminhos pode ser a eliminação da contradição, mas também nessa encruzilhada, nesse encontro de caminhos é possível cultuar justamente esse momento onde tudo se desfaz.

A arte tem sido isso pra mim, um momento e uma forma de cultuar modos de materializar essa contradição. Então na minha prática eu utilizo qualquer linguagem que me for necessária. Não tenho apego ou pena de utilizar de qualquer linguagem, pelo contrário, tenho muito prazer em ser contraditória e caminhar por tudo aquilo que o planeta me oferece, então eu crio textos, objetos com cerâmica, danço e amo utilizar vídeos, sou apaixonada pela fotografia, amo criar imagens e também espaços perecíveis de liberdade. Só nesse ano eu lancei 3 filmes, e o último se chama Uma noite sem lua em que eu uso 4 idiomas, e instauro de fato na possibilidade de gozarmos no indescritível, na Kalunga, gozarmos nessa noite sem lua, na escuridão, na incerteza.

A arte é uma forma de materializar a vida, mas ela não é pura ou límpida, é desgraçada e racista também. A materialização da vida pode ser racista, transfóbica, travestifóbica, genocida, e de fato é, só olhar a história do modernismo brasileiro, a desgraça que foi. Então artistas são violentos, a arte é violenta também, artistas aniquilam vidas, artistas destroem famílias e contribuem para o genocídio da população negra, para o tráfico internacional de nossos corpos travestis e trans, contribuem para a pobreza, artistas podem também materializar a vida que nos desloque de qualquer desejo ou pensamento genocida. 
Podemos falar de violência a partir da obra de uma grande amiga Jota Mombaça, que propõe a redistribuição da violência, mas aqui estou dizendo da violência colonial, do esquecimento, tendo em vista que o trauma racial é o trauma do esquecimento, to dizendo da violência que é o trauma racial, e não a violência do desconforto quando eu neste momento digo e compartilho com vocês a experiência de ser violentada.

Veja e sinta como os limites da palavra é um jogo perigoso e delicioso que estamos juntas criando. A palavra e o corpo. Quero terminar esse momento falando do corpo, dizendo com o corpo, porque eu como terapeuta e ao longo de toda minha graduação desenvolvi pesquisas e trabalhos contextualizados na psicologia corporal. Esse meu trabalho com a corporal caminha para o entendimento da corporificação dos traumas raciais. Como perceber o racismo em gesto, gosto, sabor, cheiro, forma de andar, sentir, sentar, guarda bolsa, ficar com medo, logo a experiência racial e de gênero também é experiência muscular, psicofisiológica, e também espiritual de algum modo. É filosófica, a violência racial é filosofia, interferência, percepção, compreensão da vida e instauração de outros modos de viver.

Então com a minha prática clínica no consultório ou na minha experiência de arte - as duas se imbricam - eu construí outros gestos e formas de se imaginar, e novamente vem a Jota Mombaça porque ela tem um trabalho bem forte com a fabulação, que dialoga com a Octavia Butler que é uma grande referência para nós duas. Voltando um pouco para o corpo, geralmente em minhas obras têm meu corpo sendo transfigurado, sendo transmutado. Sou apaixonada pela yôga, sou iniciada na capoeira d'angola, faço parte da banda de congo Vira-Mundo, a Fonte Grande é o lugar onde nasce a primeira escola de samba do Espírito Santo de vitória.

A minha família é rodeada de artistas que surgem de outros modos, tenho primo que é bailarino e cresci vendo a carreira dele se formar. Movimentos sempre acontecem em mim, e o que eu tento é pensar o movimento nessa demanda racial, da violência moderna de gênero e construir movimentos de cura. Para entender a cura é preciso se perceber além do regime temporal de infinitude, mas 
de "perecividade", então a cura é um momento perecível de liberdade. O que é liberdade? Pra mim as vezes é sorrir, comer tal coisa, conseguir meditar. Não existe fórmula ou salvação, a liberdade de cada pessoa é individual, eu digo isso a partir de uma análise crítica e clínica, compreendendo que existem outras formas de perceber a liberdade. As travestis que foram eleitas em 2020, nos convidam fazer pensar na liberdade no contexto da legislação moderna.

Meu trabalho está circunscrito nisso e eu tento criar posições e momentos onde a gente possa gestualizar. Meu trabalho vai caminhando para isso, de modo que eu viva minha animalidade corpo-flor, e o desafio é como viver minha animalidade num enredo que não seja aquele da animalização racista. O trauma racial que me coloca a todo momento como um animal impossível de ser domado, mas necessário ser domado. Pensar a animalidade sem ingenuidade nenhuma.

Essa semana eu vi uma matéria que descobriram 30 novas espécies na Amazônia brasileira, eu acho que de algum modo, a transmutação que as pessoas trans fazem, é a inauguração de uma outra espécie, é uma interferência na espécie que vem acontecendo a milhares de anos. Não estamos fazendo nada de novo. Assim como borboletas, lagartas e peixes existem há milhares de anos, nós estamos aqui. Então tenho caminhado para isso, pensar a transmutação na espécie e não na linguagem. De algum modo, pouco me importa dizer que sou negra ou travesti, o que me importa é o corpo. Com todos seus limites.

Por enquanto é isso, a gente pode começar a conversar, obrigada gente.

\section{Dodi Leal}

Axé, muito axé Castiel, muito obrigada por trazer seus questionamentos, observações e excelências. Olha mana, eu tenho feito as minhas também, minhas andanças, minhas reflexões, falamos um pouco e tenho algumas questões que vem me atravessando. Vou dividir com você como eu tenho enxergado para que possamos pensar juntas, procurando esse diálogo. Lembrei muito da conversa que você teve com a Erica Malunguinho e Lia Garcia, justamente nesse formato de troca e conversa em tempos de live. 
Pensando especificamente nesse contexto do evento, da ABCA, e falando muito desse mercado de arte que é um setor, e como você bem disse, tem uma carga de idealização tão grande que faz com que haja uma sustentação de grandes mentiras, a arte como uma grande mentira, onde supostamente não há racismo, transfobia, violência ou luta de classes porque somos artistas. A ideia de espaços de arte como museus. Hoje (na pandemia) a gente vem questionando e vivenciado práticas de espaço nas nossas próprias casas, ou onde for possível, onde a gente expande, rasga, troca e interage entre as redes. Talvez esses questionamentos sobre a espacialidade tenham outras dimensões também. E como você tem uma investida muito potente e interessante em trabalhos instalativos, temos uma reflexão dos limites de espacialidade e dessa Casa Grande que é o museu.

A Jota Mombaça tem um texto recente que é "A Plantação Cognitiva", onde ela retoma Denise Ferreira da Silva, que faz um grande estudo sobre o valor e sua formação. Um dos argumentos da Denise ao se contrapor a Marx é que a leitura marxista que vai localizar a avenção da fábula euro-estadunidense da esquerda, que a esquerda brasileira toma como legado, é a de que a invenção do capitalismo se dá na Revolução Industrial, como se aquilo que houve antes fosse apenas uma "acumulação primitiva". O que Denise faz, e Jota retoma nesse estudo de formação de valor, é mostrar que, para muitos povos escravizados, falando especificamente da colonização que, por sua vez, antecede a Revolução Industrial, não há acumulação primitiva num sistema de plantation, porque aí há uma acumulação negativa, onde alguns povos vão acumulando negativamente as projeções de dominação, fazendo esse sistema se atualizar. A plantação cognitiva hoje seria essa cotação das nossas práticas de resistência de corpos não hegemônicos.

Retomando um dos assuntos que Paul Preciado traz no livro dele Testo Junkie, - dei uma aula hoje de manhã sobre a obra do Paul e um dos textos que pedi para lerem foi o "Bioterrorismo de Gênero", onde ele fala que de certa forma, nós pessoas trans somos um software livre, de código aberto, pois o que fazemos é mostrar, e a cisgeneridade vê como faz. A cisgeneridade, por sua vez, atua numa espécei de alucinógeno, eu chamo de aluCISnação (ou A LUZ CIS NAÇÃO), ela se "autocontagia" e diz "somos todes trans". 
O que está ligado justamente a aluzCISnação, é uma ideia de nação, já que quando a gente transmuta, nos tornamos apátridas também, no sentido de deixar de ter uma nação, como se deixássemos de ser brasileiras, pois nossos fluídos corporais são controlados pelo Estado, e o poder de decisão sobre o corpo também. Todas essas formulações do Estado que vão reger nossas corporalidades têm um caráter de definir quem é verdadeiramente da nação. Por isso chamo que a cisgeneridade brisa na batatinha nesse lugar de alucisnógeno, de aluzCıSnação.

A cisgeneridade se constitui com a noção de nação. A formação dos Estados Nacionais (proveniente do pensamento europeu renascentista) também está ligado ao forjar da cisgeneridade enquanto prática de gênero colonial. O que a Jota faz nesse texto que eu acho incrível é essa nomeação do sistema de valor que a gente tem atualmente, de cotação das nossas vivências, especificamente da arte, já que ela também é artista, além de pensadora. Contrapondo a ideia do "Paul Preciado" de que somos supostamente "software livres" com códigos abertos de gênero, eu tenho dito, pensando com a Jota, que estamos vivendo necessidades de codificação das nossas práticas e existências, até fazendo um contraponto dos bitcoins, a criptografia nessa altura do campeonato faz com que não sejamos nem compradas nem vendidas. Nos tornamos a própria moeda que vai aumentar o valor dos espaços, agindo supostamente como a monetização, como um "token", se valer desse valor para pagar de bonita, pra conseguir outras coisas. Institucionalizar a travesti, a preta, o projeto indígena, já é uma moeda de valorização da branquitude cisgênera que comanda e continua no poder desses espaços.

Essa monetização a Jota chama de plantação cognitiva, eu tenho chamado de travecoins, justamente porque a gente se tornou uma moeda, e acaba que com a nossa criptografia também tem o ponto de negociação. Mas tem códigos que não vamos abrir, que não vamos passar, por isso a criptografia. Essa especulação sobre esse fetiche, “porque você está aqui, porque eu estou aqui?”, porque pessoas que não são hegemônicas não estão só fazendo arte, clínica, pesquisa, mas também fazendo crítica e curadoria, isso é muito importante destacar. Você até fala do próprio sistema de arte, como nele em si, nem a cisgeneridade branca 
chega em todos os lugares. Ela acha que está em todos os lugares mas essa arte institucionalizada não chegou no Espírito Santo, não chegou na região Norte do país, e não chegou plenamente ao Nordeste. A ideia de que podemos contrapor esses fetiches com nossos feitiços, e que "feitiçarias de travesti fazem bixa virar santa e macumba de bixa fazem travesti descansar", como você diz no teu livro Quando encontro vocês, lançado em 2019.

Então eu estou aqui pensando alto nessas ideias, como a gente propõe novas friç̧ões nesse sistema de arte, mas eu ainda acho que devemos ter mais pessoas negras, trans e indígenas fazendo curadoria, fazendo crítica. Nas Artes Cênicas, por exemplo, existe essa relação de jogo de poder na arte, não tendo esta área o mesmo valor do que é considerado "arte".

Eu não conheço outras pessoas trans que fazem crítica. Tive uma experiência de curadoria muito potente e interessante, na MITSp, Mostra Internacional de Teatro de São Paulo, em março deste ano, um pouco antes da pandemia. Na ocasião, realizamos a "Encontra de Pedagogias da Teatra: afetividades do riscar e arriscar"4 no Centro Cultural São Paulo (CCSP). Inclusive você está lá com sua obra atualmente, poderia falar um pouco se quiser.

E eu fico pensando como esse exercício da curadoria foi potente e importante, eu me encontrei em um lugar que eu gostaria de continuar exercendo, mas fiquei pensando que eu não cheguei nesse lugar porque eu já estava, então a minha curadoria não é uma modificação, mas sim uma transmutação. Vejo pessoas cis brancas, que faziam uma curadoria super inserida no mercado de artes, que agora estão chamando de "curadoria decolonial". Aí eu me pergunto se é possível fazer esse processo, fazer essa curadoria dentro do sistema hegemônico e agora essa curadoria fora. Que curadoria decolonial é essa? Ainda é uma assinatura única? Ainda traz corpos que são vitrinização e monetização da tua experiência, a qual você não pode nomear? Você não consegue nomear sua branquitude e tua cisgeneridade? Você precisa de outras pessoas?

${ }^{4}$ Encontra de Pedagogias da Teatra, curadoria de Dodi Leal, com coordenação de Maria Fernanda Vomero e direção artística de Antonio Araújo, 7a. MITsp. Disponível em: https://mitsp.org/2020/acoes-pedagogicas/ Acesso em: 22 dez. 2020 às 17h22 (Porto Seguro, Brasil). 
Só para fechar essas primeiras reflexões, dialogando com o que você trouxe, especificamente sobre a derrocada, não sei se posso falar assim... da humanidade? Da espécie? Na verdade a branquitude devastou esse mundo, pessoas cis e a macharia toda, o mundo tá machucado. Quando digo que o ato de cura é lidar com esses machucados, ou seja, com o excesso de macho no mundo, é também sobre fazer dançar essas memórias que estão nessas existências e nessas possibilidades, que é para romper com essas normas.

Esse caminho que está levando a extinção da espécie humana não é para que a gente salve ela, não é para salvar esse mundo tal qual ele se destruiu. Se ele é auto-destrutivo, ele que se foda, ele que se exploda. O que queremos é preservar as nossas histórias, daquelas que resistiram, ou inventar novos mundos que já estão em processos, que já existem há muito tempo, mesmo nesse mundo hegemônico. Sobre a espécie, escrevi uma crítica ${ }^{5}$ na MITsp deste ano, sobreo espetáculo Burgerz da Inglaterra, interpretado pela Travis Alabanza, travesti preta que foi apresentar em São Paulo pouco tempo antes da pandemia. É um espetáculo que ela criou em Londres, a partir de uma situação que ela vivenciou. Ela estava atravessando a ponte Waterloo e jogaram um hambúrguer nela. Ela ficou surpresa como ninguém se mobilizou para defendê-la naquela situação extremamente exposta. Gritavam a ela tranny (“traveco”). Então ela criou esse espetáculo, onde ela convida homens cis brancos, para fazerem um hambúrguer, como uma forma de mostrar destreza, conhecimento e provocá-los nesse processo de fazer comida.

Acredito muito, e até escrevi nesta crítica que o corpo ciborgue nunca será cis-burguês. Eu vejo muitas pessoas cis, brancas e burguesas falando sobre o corpo ciborgue e o corpo queer. Aí eu pergunto: é possível ser queer e cis ao mesmo tempo? Me parece uma contradição, não na contradição que é fabular, que vai num tempo espiralar como diz Leda Maria Martins, e que vai nos mostrar que o gênero é um processo recorrente de espiral nesse tempo, não linear. Mas

\footnotetext{
${ }^{5}$ O corpo ciborgue não será cis-burguês. Crítica da peça BURGERZ, concepção e atuação: Travis Alabanza, Reino Unido | 2018 | 1h10min | Classificação indicativa: 14 anos).. São Paulo: 7a Mostra Internacional de Teatro de São Paulo - MITsp, 2020. Disponível em: https://mitsp.org/2020/o-corpo-ciborgue-nao-sera-cis-burguespor-dodi-tavares-borges-leal/. Acesso em: 22 dez. 2020 às 15 h49 (Porto Seguro, Brasil).
} 
eu vejo que é pura linearidade mesmo, pura percepção equivocada.

Recentemente fiz um curso chamado "Tecnoética y mundo digital” por uma Universidade na Espanha, online. Me inscrevi nesse curso com a intenção de me preparar para esse processo de ser professora online. Foi ministrado por dois professores cisgêneros brancos espanhóis, um da filosofia e outro da engenharia. Nesta ocasião eu descobri que na engenharia, há algum tempo, eles têm feito pesquisas sobre transhumanismo, conjurando a relação corpo-máquina na criação do corpo ciborgue. Eu achei de um pleno desrespeito esse pensamento, por ser proveniente da Europa, de pessoas brancas e cisgêneras que tem uma vivência de corpo completamente colonial, e que não estão representando a humanidade, se é isso que elas estão querendo, elas estão pondo fim.

Essa construção quando digo que o corpo ciborgue não será cis-burguês, é porque eles imaginam sim, um transhumanismo onde será o modelo cis e branco que forjará a relação máquina e orgânico. O que estamos fazendo é uma derrocada desses parâmetros hegemônicos, mas é também aquilo que você diz, sobre ser uma ancestral do futuro, porque já somos. Então se houver um pós-humanismo, não é porque veio depois, é porque a gente teve que transformar em pó esse humanismo que está aí.

\section{Castiel Brasileiro}

Então, você me disse muitas coisas interessantes, e eu percebo a partir da sua fala que compartilhamos referências, mas estamos em posições diferentes de desejos. Nós duas articulamos demandas diferentes. A minha demanda não é a do humanismo, e eu também não me interesso pelo pós-humano. E isso não anula nada, não é uma briga de pensamentos na nossa relação eu Castiel, e Dodi. Não estamos nos anulando, pelo contrário, estamos tentando construir, nas diferenças, possibilidades de alianças, e essas alianças são sempre perecíveis, efêmeras e de formas imprevisíveis.

Quando você fala de humano, eu tenho uma forte crítica à psicanálise por exemplo, e aos processos de enegrecimento da psicanálise e psicologia. Eu 
enegreço as práticas terapêuticas, eu enegreço os pilares da psicologia, mas eu faço isso sabendo que existe um limite, porque o enegrecimento dentro desse contexto brasileiro tem sido a possibilidade de pensar a mudança de algumas bases teóricas, mudando essas epistemologias, revendo conceitos, rever ferramentas clínicas ou artísticas de curadoria, uma revisão que possibilite dizer sobre pessoas negras, travestis ou indigenas de modo ético.

O enegrecimento, ao menos no ponto de vista do sudeste no qual eu me insiro e vivo, é uma prática fundamental e necessária, mas o limite é justamente a raça, a racialização. Eu pratico o enegrecimento e ele acontece no estudo sobre a humanidade, pois de algum modo eu afirmo que somos sujeitas e em outro momento eu digo "não precisamos ser sujeitas". Essa é a contradição e o grande nó do meu trabalho, a possibilidade de habitar e de perceber como somos subjetivadas de modo subalterno, entendendo que a subjetivação a todo momento no processo de racialização do Brasil nos desloca da possibilidade de nos tornarmos sujeitas, mas o tornar-se negro é a experiência de tornarmos sujeitas subalternizadas. Então a possibilidade de construir outras humanidades também caminham nesse sentido, de afirmar que há diferença sem separabilidade, como a própria Denise Ferreira nos ensina.

A obra da Conceição Evaristo, Olhos d'Água, nos mostra tantas possibilidades de se emocionar, pensar e perceber a vida acontecendo entre nós pessoas negras, isso é fundamental para pensar a psicologia e prática terapêutica. A mitologia racial é aquela que nos coloca sempre pensando e sentindo de determinada forma, e em alguns momentos nem somos capazes de pensar ou sentir, nesse momento a humanidade me ajuda a pensar em algumas coisas. A radicalidade do meu trabalho não está no enegrecimento ou empretecimento, está na possibilidade da desracialização e na possibilidade de pensar a minha transfiguração para além do gênero. Então o meu trabalho não é sobre o gênero ou a raça, é sobre a coragem de fazer, porque se não, toda a minha complexibilidade passa a ser resumida na linearidade da raça ou gênero que eu habito, entende?

Os momentos de liberdade são justamente quando eu posso viver a minha vitalidade de forma não ordenada por essas mitologias raciais ou de gênero, 
também está algumas questões que eu tenho cobrado na obra do Preciado mas eu não tenho desejo de falar sobre ele. A obra deste autor me acompanha desde o início da minha graduação em psicologia, eu o estudo bastante, mas não para corroborar, passa justamente por um deslocamento, pois não é um gênero que me preocupa, a minha vida não acaba no gênero, caso contrário não teria transicionado, mas minha vida continua com o corpo e a possibilidade de transmutar, caminho por isso.

\section{Dodi Leal}

Bela, muito obrigada, estou muito feliz de conversar com você. Eu fiquei com vontade de saber se você preparou alguma pergunta, ou quer dialogar a respeito desse mercado da crítica e da curadoria, algo que você pense ou queira trocar ideia desse lugar.

\section{Castiel Brasileiro}

Não. Sobre a crítica e curadoria acho que de vários modos estamos dizendo sobre ela, aqui na nossa conversa, mas a minha preocupação com a crítica e curadoria no contexto brasileiro é pensar o Brasil, a violência racial no Brasil, utilizando daquilo que nomeio de "estéticas macumbeiras", como eu disse, não tenho medo da palavra. Eu faço pesquisas pelo menos nos últimos três anos sobre a palavra "macumba", essa palavra que pode ter várias origens, e vários significados, então é uma palavra tanto de xingamento, quanto uma relação de instrumento ou um movimento, com origens de vários povos que compõem a tradição Bantu.

A questão da macumbaria , é que no Brasil existe um fetiche de entender a excelência de pessoas negras na elaboração de uma experiência estética, a partir de um parâmetro miraculoso, milagroso, ou religioso espiritual: aquela pessoa negra fez um trabalho excelente, porque ela estava encorporada de algum preto velho, ou de um orixá ou vodu. Fez ou desenvolveu uma exposição em sua excelência porque ela era do candomblé e fez "macumba" pra isso. Isso é fetiche, 
isso é racismo. Recentemente eu participei de uma entrevista que a pessoa dizia justamente isso, a primeira pergunta foi essa: "Noto que a espiritualidade é uma questão comum entre as poéticas de pessoas negras”, e eu respondi que não sabia em qual pesquisa ela se fundamenta, mas eu quero entender, de qual região brasileira, de qual contexto brasileiro, qual contexto mundial que tomou a questão da religiosidade é algo comum entre nós.

A relação que o Brasil desenvolve com a diferença filosófica é uma relação subalternizada, de violência. Sempre nos nomeiam, nesse local de "outro", ou seja, espiritual e religioso, mas não se responsabilizam na própria religiosidade que fundamentam sua crítica e curadoria de arte. Porque a isso que nomeamos de religiosidade na verdade é um exercício filosófico, e a filosofia é a experiência de perceber, interferir e criar condições vitais, modos de ser e estar nesse contexto planetário e universal, no sentido de universo.

Quando você desenvolve uma curadoria que não desloca a experiência vital do regime racial, ou da cisgeneridade, você pode corroborar com a religiosidade cristã, sacou? Então no exercício de curadoria que não é pensado criticamente, existe uma prática filosófica, que se for colonial e genocida, é uma prática de conteúdos moderno cristão. Infelizmente é a forma que o cristianismo se modificou, a colonização também é cristã, também é religiosa. Se existem pessoas cristãs que desenvolvem outras possibilidades de cura, um cristianismo que não corresponda a transfobia e racismo, tudo bem, venha e me mostra quando eu tiver disponibilidade. Agora o que eu digo é de história de séculos, onde o cristianismo fundamenta nossas vidas a partir do sofrimento.

Nesse sentido, eu fico pensando sobre a "curadoria decolonial"... acho deveríamos estudar, acho que a curadoria brasileira precisa estudar a palavra, o que é a literatura. Você sabe o que é decolonial? O uso da palavra decolonial no contexto brasileiro, como que chega no contexto latino-americano, e eu não digo o estudo acadêmico, sabendo que sou acadêmica, mas também no estudo que se passa por uma intelectualidade. Porque se prender a uma palavra? Porque a decolonialidade ou a experiência que chamamos de decolonial ou anticolonial é uma experiência, não uma palavra. Porque se for uma palavra, então toda pessoa 
travestiou negra é decolonial? Toda pessoa branca é alguma coisa? Entramos nos limites da palavra. Novamente eu digo, se de fato sua curadoria é decolonial não precisa nem nomear de "decolonial", e de algum modo eu acho redundante, e em mim surge até uma preguiça, fico cansada de explicar isso. E se precisamos explicar, é porque realmente o estudo deveria ser feito.

\section{Dodi Leal}

É muito nítido né? É uma tentativa de rebaixamento intelectual.

\section{Castiel Brasileiro}

Total! Totalmente!

\section{Dodi Leal}

Eu tô aqui pululando já, com várias coisas. Queria agradecer as pessoas que estão assistindo, a conversa ficará gravada no Youtube e pretendemos publicar a transcrição, na ideia de que essa reflexão deve acontecer.

No mercado de arte tem muito uma sensação da "higienização", então o que seria esse museu, esse centro de cultura, essa universidade que pensa arte? É limpinha, é a branquinha, bem "ciszinha", que vai em todos os seus parâmetros cristãos, organizar as obras, até mesmo aquelas que rompem com a norma estão ali, digamos, envidradas, petrificadas num contexto de vitrine. Eu tenho a sensação, e até reverberando um pouco com oque você comentou, tanto na conversa com a Lia Garcia ${ }^{6}$, quanto na EAD (Escola de Arte Dramática) 7 , sobre sujeira, e tenho uma pergunta. É possível uma curadoria decolonial e continuar limpinha, continuar com esse higienismo? E esse clean não é só do espaço. É realmente uma ideia de perfeccionismo que difere da nossa excelência travesti. É um perfeccionismo

${ }^{6}$ TEMPOS PARA A CURA. ESPAÇOS PARA SER. Resistências anticoloniais Travestis desde a espiritualidade - conversa entre Castiel Vitorino Brasileiro e Lia Garcia. Disponível em: https://www.youtube.com/watch?v=6pggiDlyTHg. Acesso em: 22 dez. 2020 às 15h43 (Porto Seguro, Brasil). 
cisgênero que vai se construir numa perfeição. A única valia dela é o alvejante, a única coisa que ela agrega valor na arte é o produto de limpeza do discurso. Ela não produz praticamente nada, pois para se envolver é preciso sair desse pedestal.

\section{Castiel Brasileiro}

Sim, porque o que acontece na questão da limpeza e sujeira está profundamente relacionamento com o status de sujeito límpido que a própria Denise Ferreira da Silva me ensina em seu livro "A Dívida impagável", sobre a construção desse sujeito moderno como sujeito límpido. Podemos ir pra história do iluminismo com o próprio regime da luminosidade, dar e levar luz. Isso está profundamente relacionado com a instauração colonial de um tempo linear, nisso temos que tomar cuidado para não abandonarmos o tempo linear e viver o tempo espiralado. No contexto brasileiro é assim, quando descobrimos um erro nós abandonamos, mudamos e criamos essa fórmula.

Pode ser curadoria decolonial, curadoria antirracista, curadoria travesti, e vai se criando várias fórmulas identitárias que não se preocupam com a história da palavra. A limpidez e a luminosidade está profundamente ligado ao regime linear da vida, que é um regime que estrutura o nosso mundo, então precisa ser visto, revisto e deslocado dele, mas o que tento fazer também é entender como o tempo linear é apenas uma forma de perceber o mundo, uma forma que foi utilizada para instaurar violências. Mas não sei ainda se o tempo linear em si é violento, entende? Entendendo que nós vivemos dentro desse contexto brasileiro e que nós já nascemos no contexto de linearidade, mas o nosso corpo e existência pré existe, e se desloca dessa temporalidade linear.

Existem sociedades Banto que se organizavam em 4 dias, a semana tinha 4 dias semanais e não 7. Então, como dito por Castiel, a nossa demanda é criar uma semana de 4 dias Não! não me tratem desta forma. A demanda é criar outra semana? A demanda é todo mundo transicionar de gênero? A demanda é ninguém ser mais branco? A minha fala sobre sujeira está muito contextualizada no contexto brasileiro, fundamentada na eliminação de um passado contraditório. E isso deve ser avaliado a partir da experiência da branquitude em suas 
particularidades e em sua coletividade, mas também na experiência em que cada pessoa se relaciona com a contradição.

Isso porque minha fala não caminha para a instauração de uma legislação, mas sim uma fala clínica, e na clínica como muito me ensina a Neusa Santos Souza, por seu Torna-se Negra como psicanalista, que suicidou-se na primeira década do século XXI, a clínica me convoca a todo momento a pensar nas nossas existências singulares acontecendo e se formando na experiência coletiva, mas a clínica também é fundamentada na impossibilidade de dizer sobre uma vida a partir de uma fala e de uma análise, que desconsidere a particularidade dessa pessoa. Então sim, somos pessoas constituídas, atravessadas e formadas por questões identitárias pela branquitude no seu caso ou pela negritude no meu, mas de modo singular vivenciamos isso, e de modo singular vamos se contrapor. Então cada pessoa vai para a guerra com o corpo que tem, e devemos ter cuidado.

\section{Pergunta por José Antônio Fogueira}

Queridas Dodi e Castiel a transmutação de existências fluidas de corpos e linguagem pode ser um sinal em enxergar a arte como instrumento de reexistências destas corpas?

\section{Dodi Leal}

Sim, porque quando a gente transmuta, colocamos em xeque realmente as vivências e referências estéticas que temos. Isso que falamos logo a pouco que transmutar é receber a cidadania apátrida. É receber o card de que não temos mais o mesmo valor de cidadã de uma pessoa cisgênera. Também é a localização de que mundo que você fala. Qual o teu lugar de trava? Fazendo ecoar uma obra da Castiel $^{8}$. Justamente porque vemos a referência estética artística completamente diferente. A gente cria a nossa arte também.

\footnotetext{
${ }^{8}$ Local de Trava. Instalação de Castiel Vitorino Brasileiro. Exposição coletiva Gira, Museu Capixaba do Negro Mucane. Vitória, 2019. Disponível em: https://castielvitorinobrasileiro.com/inst_localdetrava. Acesso em: 22 dez. 2020 às 16 h00 (Porto Seguro, Brasil).
} 


\section{Castiel Brasileiro}

Exatamente. Do mundo que a gente fala, na transição por exemplo, existe aquela, e eu sou uma delas, que negocia com a passabilidade cisgênera. O que eu digo é para que possamos entender a particularidade da transmutação, da transição de gênero não somos iguais umas as outras, mesmo que a palavra travesti e o gênero travesti seja uma experiência coletiva, experiência histórica, onde a tecnologia da medicina e cirurgia acontece desde o período pós-guerra, os usos de matérias interferidos em nossos corpos.

Chega a ser violento e cansativo dizer aqui junto a Dodi que cada travesti é uma particularidade, se a gente precisa afirmar isso, é porque existe uma idealização do local de travesti, sacou? Porque eu digo isso? Porque na transição de gênero existem pessoas que ainda utilizam como referenciais aqueles que não são nossos, e também não quero fazer uma fala explicando o que é travesti ou não, acho que não passa por isso. Se passa também das minhas experiências de travestilidade e negritude, lembrando que travestilidade e negritude são apenas duas palavras que resumem de modo perigoso e violento as nossas existências.

Digo isso devido a despatrialização que acontecem de algum modo a todas existências trans, justamente por serem trans, mas nossas experiências transsexuais e travestis são diferentes, são demarcadas pela branquitude, questões de classe e sexualidade. O genocídio da população negra também é o genocídio da população travesti, no contexto do Espírito Santo por exemplo 60\% das travestis que se prostituem são negras, não faço um discurso moralizante sobre a prostituição, digo sobre a vulnerabilidade. Não é perceber a travestilidade ou transsexualidade como lugar ideal, como normalmente gays brancos têm feito, sacou? É entender que a questão da transsexualidade tá pra além da travestilidade e as pessoas não binárias estão aí pra dizer sobre isso.

\section{Dodi Leal}

Queria tanto ouvir mais sobre tua obra artística, seus trabalhos. E o seu atual 
também, o "Nada aqui se acaba"9.

\section{Castiel Brasileiro}

Posso dizer. Você disse sobre construir experiências estéticas que não aconteçam no lugar do museológico, é uma pesquisa que eu faço a um bom tempo, pois sou apaixonada pela possibilidade de construir espaços, eu amo. A questão pra mim é que eu estudo bastante os Quilombos, tendo em vista que a Fonte Grande onde eu nasço é uma região quilombola, não institucionalizado pelo estado brasileiro como região quilombola, mas é. Esse ano fiz minha primeira viagem internacional, e eu fico pensando já que estou no Brasil e quero ter prazer, como posso criar um local de prazer nesse espaço sem ingenuidade mas com responsabilidade?

Então eu comecei a estudar a instauração de templos religiosos no contexto brasileiro, levantando um terreiro de Umbanda, Omoloko, Candomblé, Jurema, Quimbanda, a feitura dessas casas me ensina a possibilidade de construir um local perecível de liberdade, porém a liberdade não é um local, mas sim uma situação, uma experiência. Dentro desses terreiros de umbanda por exemplo, muito se pratica a violência colonial de gênero, onde travestis são entendidas e não são respeitadas como travesti ou mulheres trans, mas como homens, existe a travestifobia dentro dos terreiros de umbanda, existe o racismo também que constituem a história da umbanda brasileira, que dizia que não se poderia cultuar memórias de Pretos-Velhos, ou seja, de pessoas africanos escravizados em contexto brasileira.

A feitura de um espaço não garante nada, não salva ninguém, e com as minhas obras de instalação são criações de espaços formados onde há possibilidades de viver a liberdade. Nessa última instalação que criei no Centro Cultural São Paulo, é uma instalação circular de 4,5 m de diâmetro, com altura de 2,20m, é um grande círculo preenchido por 210 quilos de terra, 6 litros de azeite,

9 Nada aqui se acaba. Instalação de Castiel Vitorino Brasileiro. Centro Cultural São Paulo. São Paulo, 2020. Disponível em: https://castielvitorinobrasileiro.com/inst_nadaaquiseacaba. Acesso em: 22 dez. 2020 às 16 h03 (Porto Seguro, Brasil). 
vários litros de champagne, cachaça e água, essa obra tem uma encruzilhada formada por 3 displays onde em cada um acontece uma série de vídeos que se chama Frequência dessa encarnação (2020) que são 6 vídeos, e com os vídeos rolando o som se instaura no espaço, criando uma experiência de mistura. É uma encruzilhada, mas a encruzilhada de tomada de decisão, não apenas contemplação dos caminhos.

Essa instalação se chama Nada Aqui Se Acaba, nada na encruzilhada se acaba, o que há é a possibilidade de entrar, instaurar, contemplar as possibilidades que tem e se anunciam no caminho, mas também decidir em qual caminho trilhar. Nessa obra você pode trilhar o caminho de olhar pro mar, assistir um vídeo ou outro, ir embora, não entrar, mas a obra como uma experiência clínica nos conduz a pensar sobre nossa própria vida. Então, você tá em uma encruzilhada identitária, qual local vital você desenvolve a partir dali? Transmutando a culpa por uma responsabilidade, bem, se você é constituída pelas categorias hegemônicas identitárias, cria-se aí uma responsabilidade em relação a isso. Nada aqui se acaba vai acontecer até fevereiro de 2021 e tem curadoria do querido Hélio Menezes, faz parte da exposição Abre Caminhos no Centro Cultura São Paulo. É um convite, vamos assistir, estou muito feliz com essa obra. No meu site WWW.castielvitorinobrasileiro.com tem uma página destinada a essa obra onde tem um vídeo onde eu contextualizo com mais calma e tempo, a feitura dessa obra, com registros audiovisuais e sua construção.

\section{Dodi Leal}

Ai, eu queria tanto ir, queria tanto ver, mas não será possível dessa vez. Mas espero que você venha aqui pra UFSB, para o Sul da Bahia em breve.

\section{Castiel Brasileiro}

Sim. Eu quero construir um quarto de cura aí na Bahia.

\section{Dodi Leal}

Espero que seja aqui no Sul da Bahia, com a gente. Porque é isso, né? Um 
encontro presencial também é um lugar de tomar decisão, não é só contemplar o caminho, encruzilhada é também uma "encruzitrava" né? Eu falo "encruzitrava" inclusive pensando muito nos boys cisgêneros que se relacionam com travestis e se excitam, "ai mais com você eu posso ter liberdade de usar uma roupa feminina", e essa "aluCISnação" é muito tóxica porque é um abuso. Como as pessoas cisgêneras não percebem isso. Estas circunstâncias se dão nas nossas vidas afetivas, mas também em contextos de trabalho. As tokenizações. Como somos abusadas e exploradas intelectualmente, colocadas num lugar de limite para ver até onde a gente consegue aguentar.

Eu particularmente sendo a única professora mulher trans no ensino público federal na área de artes, eu sinto um peso imenso sobre meus ombros, Castiel. No sentido da responsabilidade de abrir caminhos para outras pessoas trans também. Mas dessa objetificação sobre o meu trabalho, que acaba acontecendo pela sobrecarga, pelo excesso, pela provação, tem que trabalhar 30 vezes mais. Assim como acontece com pessoas negras, que têm que trabalhar muito mais para provarem que são capazes. É muito adoecedor esses modos de trabalho. Então, fica o recadinho: deixem a travesti descansar! Não, acho que não é deixar, né? É o feitiço.

\section{Castiel Brasileiro}

Criar condições, eu acho que é criar condições para o descanso. Porque a feitura dessas condições de fato, é coletiva.

\section{Dodi Leal}

Sim, então, quando esta sociedade decidir ter mais professoras trans, na área de artes e em todas as áreas, a gente vai precisar ter mais condições.

Então, este é um espaço também ligado à minha aula, o curso de Pedagogias da Cena aqui na UFSB. Recebemos a pergunta de um estudante a respeito do texto da Leda Maria Martins "Performances do Tempo Espiralar", que lemos e discutimos em aula. E ele traz essa pergunta a partir dessa referência da Leda. 


\section{Pergunta por Marconi Sales}

A encruzilhada seria como uma espiral?

\section{Castiel Brasileiro}

Sim, eu recomendo também a obra de Leandro Rocha/Napê Rocha a sua dissertação de mestrado, fala sobre encruzilhada e é uma análise da obra de Paulo Nazareth, dialogando bastante com a obra da Leda Maria Martins.

Sim, eu acredito que a encruzilhada é uma espiral sim, mas não vou adentrar agora nessa questão porque eu preciso estudar um pouco mais, uma questãozinha dentro da encruzilhada, para poder responder com mais força e firmeza a questão da espiral, preciso mergulhar com mais intensidade na obra da Leda, nesse sentido tô esperando os novos livros que ela vai lançar.

Nesse movimento de espiral é gostoso, porque me lembra o próprio DNA, de algum modo, e eu me sinto mais confortável para falar sobre a encruzilhada a partir de epistemologias Banto, por exemplo quando o professor Tiganá Santana que tem um trabalho lindo sobre a diáspora Bakongo, me traz uma questão para esses povos em específico que eu entendo como encruzilhada, é o Cosmograma Bakongo. Esse cosmograma organiza-se com os 4 momentos do sol, o ápice que é o meio dia que é o Tukula, o mergulho, a entrada no mundo dos mortos é o Luvemba, o ponto mais profundo do sol, ou seja, a grande noite é o Musoni, e o renascimento do sol é Kala, a possibilidade de ser, mas não como identidade e sim como força. Esses 4 momentos do sol são momentos diários, todos os dias ele nasce, alcança o ápice, escolhe morrer como transmutação não como aniquilação, e a morte como a entrada nesse mundo dos mortos, como a própria experiência de entrar no mundo das memórias.

Quatro pontos, quatro sóis, esses quatro sóis formam uma encruzilhada, mas esse cosmograma acontece de modo “3D", pois acontecem 4 momentos, 4 direções pra vida. Tiganá traduz a obra do Kimbwandènde Kia Bunseki Fu-Kiau. São 7 direções que a vida pode estabelecer, esquerda, direita, cima, baixo, frente, trás e a sétima direção que é a mais importante seria a caminhada para o meio, pra si 
própria. Sobre essas 7 direções eu criei um trabalho fotográfico que se chama $O$ sétimo caminho da encruzilhada é o equilibrio ${ }^{10} 2020$, é um autorretrato onde desenvolvo posições de yôga com meu corpo, essas posições criam gestos de encruzilhadas, gestos de espirais, eu desenvolvo posições de yôga de equilíbrio, e misturo nas sobreposições desses movimentos. Eu modifico o obturador da câmera, para que modifique o tempo de captura das imagens, alargando o tempo de captura. Então não há uma sobreposição, mas sim um registro do lastro que meu corpo faz para atingir o equilíbrio. Essa obra foi construída nesse contexto de 7 caminhos, caminho pra si própria, para o autoconhecimento.

O Renato Santos, é o meu mestre de congo, mestre pra vida, também professor de dança e pedagogo, ele diz assim: "quando você não souber para onde ir, faça o caminho de volta". Então eu acho que esse trabalho e toda minha vida de alguma forma é fazer o caminho de volta, e isso é linearidade também, é habitar de algum modo a linearidade de outro modo, e negociar com ela, e fazer o caminho de volta.

\section{Dodi Leal}

Uma última questão, pois estamos indo pro final. Justamente fazendo essa conexão com o cosmograma e como você tem feito essa relação com a yôga, lembrando da conversa com a Lia Garcia, você mencionou sobre as gestualizações e as sensualizações das posições de yôga, que eu acho linda. Eu tenho feito essa pesquisa corporal, de desgenitalizar os órgãos genitais, erogenizar áreas do corpo que não são erógenas, e de perceber como estabelecer novos contratos de sexualidade e sensualidade que vão romper com as gestualidades que a gente conheceu.

Eu achei muito bonito essa tua experiência, que eu penso que conecta de alguma forma com meu trabalho de curadora, que é o cu como um epicentro epistêmico. Pensando um pouco com a Pêdra Costa quando ela retoma

10 O sétimo caminho da encruzilhada é o equilíbrio. Castiel Vitorino Brasileiro. Fotografia. Vitória, 2020. Disponível em: https://castielvitorinobrasileiro.com/_foto_osetimocaminho. Acesso em: 22 dez.2020 às 17 h26 (Porto Seguro, Brasil). 
Boaventura dos Santos e fala: aqui meu bem, não é epistemologias do Sul, é epistemologias do Cu, porque o cu funciona, e é a fonte de produção de conhecimento do corpo e do mundo, onde a gente tem esse pensamento anal. Diante de um mundo banal, um pensamento anal.

Fico pensando, sobre o seu ponto de vista, qual a relação entre cu e cura, ou cu e curadoria?

\section{Castiel Brasileiro}

Total, é a sobrevivência. Dodi, foi ótimo você falar sobre isso, porque eu estou desenvolvendo um trabalho de meditação guiada, meditações guiadas para o cu, onde a gente consiga tocar o cu. Faz parte de um trajeto meu com a produção de sonoridades de cura, entendendo que o som é um elemento fundamental para desenvolver a experiência do transe, nas macumbarias por exemplo.

A feitura do podcasté uma forma de inaugurar sons que inauguram transe, e agora também tenho trabalhado áudios de cura, estando muito fundamentados nos meus estudos e experiências com os chakras, o que os chakras nos ensina é de fato uma outra anatomia. E o primeiro chakra, o órgão correspondente a ele é o próprio cu, é o ânus, assim como o segundo chakra que é o da criatividade, sensorialidade, onde brota energia vital, está localizado entre as pernas.

Então essas epistemologias, essas filosofias indianas me ensinam isso, sobre uma outra possibilidade de corpo e funcionalidade de órgãos, que não correspondem a um regime pornográfico, no sentido misógino ou racista. Estou desenvolvendo esse trabalho junto com um DJ de funk, artista, estilista, se chama Herdeiro Prince, e todas as meditações possuem batidas de funk, porque o funk como um todo, é uma grande tecnologia brasileira de instaurar situações corpóreas, que estimulam principalmente os dois primeiros chakras, o primeiro muladhara que se relaciona com a sobrevivência e a possibilidade de cultuar memórias, e o segundo que é a swadhisthana, esse das genitálias.

O cu é a sobrevivência, a possibilidade de você tocar e futucar as suas memórias de sobrevivência, e no funk quando a gente mexe o cu, mexe a bunda 
e rebola, estamos estimulando justamente essa área. O sentido que mais predomina na sobrevivência é o olfato, nossa sobrevivência também está profundamente relacionada com a nossa possibilidade de sentir cheiros, instaurar cheiro. Por isso em minhas obras instalativas há muitos cheiros. E o cu pra mim é tudo isso.

\section{Dodi Leal}

Eu ia falar assim pra você, que já num tom de agradecimento, que a Universidade Federal do Sul da Bahia está escancarada pra você, mas eu acho que vou dizer que a Universidade Federal do Cu da Bahia está escancarada pra você. Que você venha nos visitar, dar aula, compartilhar teus saberes, produzir arte se você quiser. Vai ser um prazer muito grande apresentar a você nossos trabalhos, nossas estudantes. Temos a maior política afirmativa do país em termos de cotas, 70\% das vagas são destinadas a pessoas trans, negras, indígenas, quilombolas, ciganas, com deficiência, em alguns casos de pós-graduação, com prioridade também para pessoas que são professoras da rede pública. Em geral as universidades que têm cotas, elas conseguem até 30\% do seu percentual, deixando 70\% para a concorrência.

A UFSB é uma universidade minúscula, com orçamento muito baixo, sofreu um corte enorme com esse desmonte da educação e cultura do país. Mas estamos resistindo, estamos criando nossos cursos, fazendo arte. Então, nessa pequena universidade, do ponto de vista das nossas existências, das miudezas e do tempo linear que ela existe, são só 7 anos, adoraríamos nos aproximar mais, falo também por mim, quero tá muito mais próxima de ti, a teu dispor, para que continuemos tecendo conversas e trocas. Muito obrigada Castiel.

\section{Castiel Brasileiro}

Obrigada, eu quero agradecer imensamente a você Dodi, pelo convite, pela acolhida, pelas tantas conversas que antecederam. Agradecer também ao seminário e toda equipe da associação. Agradecer a equipe técnica que está nos 
possibilitando. Agradecer as pessoas que estão ouvindo com atenção e cuidado, persistindo até o final com a gente. Agradecer as pessoas que possibilitaram estamos aqui, nossas ancestrais travestis, indígenas, negras, e algumas aliadas brancas também né?

E também quero agradecer a mim mesma, pela coragem de estar aqui. Obrigada, Castiel.

Recebido em: 06/01/2021

Aprovado em: 19/04/2021 